\title{
A COMPARISON OF THE CONCENTRATIONS OF ENERGY-BALANCE-RELATED VARIABLES IN JUGULAR AND MAMMARY VEIN BLOOD OF DAIRY COWS WITH DIFFERENT MILK YIELD
}

\author{
Horea ŠAMANC ${ }^{1}$, Danijela KIROVSKI ${ }^{2 *}$, Nada LAKI'́ ${ }^{3}$, Irena CELESKA ${ }^{4}$, \\ Slavica BoJKOVIĆ-KOVAČEVIĆ ${ }^{5}$, Željko SLADOJEVIĆ ${ }^{6}$ and Ivan IVANOV ${ }^{1}$ \\ ${ }^{1}$ Department of Farm Animal Diseases and ${ }^{2}$ Department of Physiology and \\ Biochemistry, Faculty of Veterinary Medicine, University of Belgrade, \\ Bulevar Oslobođenja 18, 11000 Belgrade, Serbia; ${ }^{3}$ Department of Agroeconomy, \\ Faculty of Agriculture, University of Belgrade, Serbia; ${ }^{4}$ Department of Pathophysiology, \\ Faculty of Veterinary Medicine, Skopje, Macedonia; ${ }^{5}$ Veterinary Station, \\ Agriculture Cooperation, Belgrade, Serbia; ${ }^{6}$ Veterinary Station 'Veterina System \\ Sladojević', Gradiška, Republic of Srpska, Bosnia and Herzegovina
}

(Received 6 February 2012; accepted 11 December 2012)

The aim of this study was to compare the concentrations of blood variables obtained simultaneously from the jugular and mammary veins of dairy cows. Eighty Holstein cows were divided into four equal groups: dry, low- (LY), medium- (MY) and high-yielding (HY). Blood insulin, glucose, non-esterified fatty acid (NEFA), beta-hydroxybutyrate (BHBA) and urea concentrations were measured. The jugular and mammary vein $(\mathrm{J} / \mathrm{M})$ ratio between concentrations of each variable was calculated. Differences between the groups of cows in concentrations of variables in the jugular vein were not in accordance with those obtained for the mammary vein. $\mathrm{J} / \mathrm{M}$ values for insulin and glucose concentrations were above 1.0 in all groups of cows. The ratios for NEFA and BHBA concentrations were under or equal to 1.0 in dry and LY cows but above 1.0 in the MY and HY groups, indicating that in MY and HY cows those metabolites are apparently utilised by the mammary gland. $\mathrm{J} / \mathrm{M}$ values for urea were above 1.0 in dry and LY cows but less than 1.0 in groups MY and HY, indicating that in the latter case urea is apparently released by the mammary gland. In conclusion, $\mathrm{J} / \mathrm{M}$ for NEFA, BHBA and urea may be useful for estimation of the critical point when the mammary gland receives insufficient energy precursors for its current activity.

Key words: Energy balance, mammary vein, jugular vein, dairy cow, milk yield

Energy balance (EB) is calculated as the difference between energy consumption in the diet and energy use by the body to support maintenance, growth, milk

\footnotetext{
*Corresponding author; E-mail: dani@vet.bg.ac.rs; Phone: 00381 (642) 216-963; Fax: 00381 (112) 685-936
} 
production and reproduction. High-yielding dairy cows experience negative energy balance (NEB) in early lactation, because feed intake cannot provide the required energy for milk yield and maintenance. However, there are large differences between animals in the magnitude of NEB, which is important, due to the association of EB with milk production, health and fertility (Le Blanc, 2010; Gumen et al., 2011).

Blood variables like glucose, non-esterified fatty acid (NEFA), betahydroxybutyrate (BHBA) and urea concentrations are widely used indicators of EB status (Cozzi et al., 2011). With the onset of lactation and the associated NEB, glucose concentration in the blood, which is essential for milk lactose synthesis, decreases. Simultaneously, NEFA and BHBA concentrations increase, to provide additional energy for maintenance and milk production. Among the wide variety of interrelated parameters, circulating urea concentration is influenced by the amount and rumen degradability of dietary carbohydrate and can be a good indicator of energy supply to the cow (Laven et al., 2007). Namely, the ammonia produced through protein degradation in the rumen can be used by the rumen microflora only if the amount of readily fermentable carbohydrates is sufficient. The physiological balance is obtained with a ration containing $14 \%$ protein (Kirchgessner and Kreuzer, 1985), which is sufficient in most of the cases for a daily milk yield of $20 \mathrm{~kg}$. With increasing milk production, the protein/energy ratio of feed gets higher, resulting in an increase of ammonia that cannot be used by the rumen bacteria. As urea production in the liver increases, an elevation of blood and milk urea concentrations follows (Oltner and Wiktorsson, 1983).

It is widely accepted that blood for the determination of variables to be used for the estimation of energy balance of early-lactation dairy cows, is sampled from the jugular vein. There are only few studies in which parameters for this purpose have been determined in blood taken from mammary or tail veins (González et al., 2011). It was noted that, in some cases, metabolite concentrations differ in blood from different veins, such as jugular and mammary, which may be attributed to the apparent mammary uptake or release of these substances (Gagliostro et al., 1991). Since the apparent mammary uptake of some blood metabolites is of crucial importance for estimating a cow's energy status, we postulated that determination of blood variables obtained simultaneously from mammary and jugular veins might provide additional information about the energy status of early-lactation cows. We calculated jugular/mammary venous ratios of several metabolites instead of measuring mammary arteriovenous difference (Cant et al., 1993; Rius et al., 2010), which is a widely accepted technique for the determination of mammary uptake of metabolites, since the latter cannot be performed in the practice when the metabolic status of cows is evaluated under farm conditions.

The aim of our study was to determine the apparent mammary uptake and release of some energy-balance-related blood variables in dry cows and cows in early lactation with different milk yields, to compare the concentrations of some blood analytes simultaneously in the jugular and mammary veins. 


\section{Materials and methods}

Cow selection

Eighty clinically healthy Holstein cows were chosen from the dairy herd of a large commercial farm (PKB Corporation, Belgrade). The selected cows ranged from 4 to 6 years of age and were housed in a tie-stall barn. They were divided into four groups of equal size. The first group consisted of 20 dry cows at day 30 before the expected calving. The second, third and fourth groups each included 20 cows at day 30 of lactation, but with different milk yields: lowyielding cows (LY, 31 to 40 litres per day), medium-yielding cows (MY, 41 to 50 litres) and high-yielding cows (HY, more than 50 litres per day).

The animal-related component of the study was approved by the Ethical Committee of the Faculty of Veterinary Medicine, University of Belgrade in accordance with the National Regulations on Animal Welfare.

\section{Feeding management}

The ingredients and the chemical composition of the diets for dry and early-lactation cows are listed in Tables 1 and 2. Regardless of milk yield, all cows received the same amount of feed for the first 30 days of lactation, as this is the feeding strategy applied at the commercial dairy farm where the experiment was carried out.

Table 1

Ingredients of the diets for dairy cows

\begin{tabular}{lcc}
\hline Ingredient (kg/day) & During the dry period & Until day 30 of lactation \\
\hline Alfalfa hay & 3.00 & 3.50 \\
Wheat straw & 2.60 & - \\
Alfalfa haylage & 3.50 & 1.00 \\
Corn silage & 10.00 & 17.50 \\
Extruded fullfat soybeans & - & 2.00 \\
Sugarbeet molasses & - & 0.30 \\
Dry sugarbeet pulp & - & 0.75 \\
Corn grain meal & 1.45 & 3.79 \\
Barley grain & 0.27 & 0.90 \\
Sunflower meal & 0.85 & 3.51 \\
Wheat flour & 0.50 & 0.90 \\
Dicalcium phosphate & 0.04 & 0.10 \\
Calcium carbonate & 0.04 & 0.24 \\
Sodium chloride (iodised) & 0.02 & 0.13 \\
Vitamin-mineral premix & 0.03 & 0.10
\end{tabular}

${ }^{*}$ Composition of vitamin-mineral premix: vitamin $\mathrm{A}(1,500,000 \mathrm{IU})$, vitamin $\mathrm{D}_{3}$ (300,000 IU), vitamin E (4,000 mg), niacin (2,000 mg), biotin $(20 \mathrm{mg})$, iron (3,000 mg), copper $(1,200 \mathrm{mg})$, manganese $(6,000 \mathrm{mg})$, zinc $(5,000 \mathrm{mg})$, iodine $(100 \mathrm{mg})$, selenium (30 mg), cobalt (40 mg), magnesium (5 $000 \mathrm{mg})$, antioxidant $(10,000 \mathrm{mg})$. The vitaminmineral premix is manufactured by PKB Corporation, Belgrade, Serbia 
Table 2

Ingredients of the diets for dairy cows

\begin{tabular}{lcc}
\hline Chemical composition & During the dry period & Until day 30 of lactation \\
\hline DM, kg/day & 11.8 & 22.1 \\
Net energy of lactation (NEL), MJ/day & 72.0 & 148.2 \\
Metabolisable protein (MP), g/day & 940.0 & 2142.0 \\
Rumen degradable protein (RDP), g/day & 1110.0 & 2743.0 \\
Rumen undegradable protein (RUP), g/day & 388.0 & 1025.0 \\
Crude fat, \% DM & 2.6 & 4.7 \\
Non-structural carbohydrates & 35.0 & 39.3 \\
Acid detergent fibre (ADF), \% DM & 29.9 & 22.0 \\
Neutral detergent fibre (NDF), \% DM & 44.7 & 33.2 \\
NDF from forage, \% DM & 39.2 & 20.6 \\
Ca, g/day & 41.0 & 66.0 \\
P, g/day & 32.0 & 25.0 \\
K, g/day & 161.0 & 88.0
\end{tabular}

\section{Milk yield and composition}

Milk yields were measured at the morning and evening milking (6:00 and 18:00) using Milk Master equipment (De Laval, Australia). Milk samples were analysed for composition using Milko-Scan 33 (Foss Electric, Hillerod, Denmark). Average daily milk yields on day 30 of lactation were $32.75 \pm 0.53 \mathrm{~L}$ (LY), $43.15 \pm 0.59 \mathrm{~L}$ (MY) and 54.55 $\pm 0.86 \mathrm{~L}$ (HY). Differences in milk yields between the groups were significant $(\mathrm{P}<0.001$, respectively) and were expected due to the experimental design. Average milk fat contents were $3.71 \pm 0.05 \%$ (LY), $3.63 \pm 0.08 \%(\mathrm{MY})$ and $3.56 \pm 0.07 \%$ (HY), and did not differ between the groups. Average milk protein contents were $3.25 \pm 0.02 \%$ (LY), $3.19 \pm 0.03 \%$ (MY) and $3.12 \pm 0.05 \%$ (HY) and differed significantly between the LY and HY groups $(\mathrm{P}<0.01)$.

\section{Blood collection}

Blood samples from each cow were taken simultaneously from the jugular and mammary veins 2 to $3 \mathrm{~h}$ after the morning feeding. Samples for insulin, NEFA, BHBA and urea analysis were obtained with a sterile needle into plain tubes and allowed to clot spontaneously for approximately $15 \mathrm{~min}$. After centrifugation at $1,000 \mathrm{~g}$ for $20 \mathrm{~min}$ the serum was decanted and stored at $-20^{\circ} \mathrm{C}$ until analysed. Sodium-fluoride-oxalate tubes were used for glucose determination. Insulin was determined using a commercial RIA kit (INEP Zemun) intended for human sera but validated for bovine sera. Cross-reactivity of the antihuman insulin antibodies with bovine insulin was close to $100 \%$. Standards for the radioimmunoassay were made from bovine insulin. Intra- and interassay co- 
efficients of variation (CV) for the insulin concentrations were less or close to $10 \%$ and less than $5 \%$, respectively. Concentrations of NEFA were measured using an enzymatic colorimetric method (Randox, Great Britain), BHBA by a NAD-dependent enzymatic UV method (Randox, Great Britain), urea by a fully enzymatic method (Human, Germany) and glucose by an enzymatic colorimetric method (Human, Germany). The samples were processed in a semi-automatic biochemical analyser (Stat Fax ${ }^{\circledR} 3300$ Chemistry Analyzer, Awareness Technology, Inc., Palm City, FL, USA).

\section{Statistical analysis}

The results obtained were analysed statistically using Statistica v. 6 (StatSoft, Inc., Tulsa, OK, USA). As average values, arithmetic means were determined for homogeneous data and medians for heterogeneous values in a group. Since many data were not homogeneous (CV higher than $30 \%$ ) or normally distributed, the significance of differences between average concentrations of blood variables in the jugular and mammary veins were evaluated using the Wilcoxon matched pairs test. The differences of average values of the analysed blood variables between groups of cows was computed using the Kruskal-Wallis test and the Mann-Whitney U-test.

\section{Results}

Jugular vein insulin concentrations were significantly lower in lactating cows than in dry cows (Table 3). In the LY, MY and HY groups, jugular insulin concentrations decreased by $27.15 \%, 42.05 \%$ and $49.32 \%$, respectively, when compared to dry cows. Mammary vein insulin concentrations were significantly lower in lactating than in dry cows, and decreased by $28.72 \%, 44.11 \%$ and $65.13 \%$, respectively, when compared to dry cows. The $\mathrm{J} / \mathrm{M}$ ratio for insulin concentrations was above 1.0 in all groups of cows, and was significantly higher in Group HY than in all other groups. The Wilcoxon test showed significant differences between jugular and mammary insulin concentrations in each group of cows (Table 3).

Jugular vein glucose concentrations did not differ significantly between the groups of lactating cows, but were considerably lower in lactating than in dry cows (Table 4). Mammary vein glucose concentrations were significantly lower in all lactating groups than in the group of dry cows, and also decreased significantly with increasing milk yield. In Group HY, jugular glucose concentration was $83.58 \%$ of the value determined in dry cows, while mammary glucose concentration was $42.19 \%$ of the value determined in dry cows. The $\mathrm{J} / \mathrm{M}$ ratios for glucose concentrations were above 1.0 in all groups of cows. The Wilcoxon test showed significant differences between jugular and mammary vein glucose concentrations in all examined groups of cows (Table 4). 
Table 3

Insulin concentration in jugular and mammary veins and their ratio in dry and milking cows

\begin{tabular}{lccccc}
\hline \multirow{2}{*}{ Insulin concentrations $(\mu \mathrm{U} / \mathrm{L})$} & \multicolumn{5}{c}{ Group } \\
\cline { 3 - 6 } & & $\mathrm{DRY}$ & $\mathrm{LY}$ & $\mathrm{MY}$ & $\mathrm{HY}$ \\
\hline Jugular vein $^{*}$ & $\mathrm{M}_{\mathrm{e}}$ & $22.1^{\mathrm{a}}$ & $16.1^{\mathrm{b}}$ & $12.8^{\mathrm{c}}$ & $11.2^{\mathrm{c}}$ \\
& $\mathrm{LQ}$ & 14.9 & 14.5 & 10.6 & 9.5 \\
& $\mathrm{UQ}$ & 24.3 & 18.6 & 16.1 & 13.5 \\
\hline Mammary vein $^{*}$ & $\mathrm{M}_{\mathrm{e}}$ & $19.5^{\mathrm{a}}$ & $13.9^{\mathrm{b}}$ & $10.9^{\mathrm{c}}$ & $6.8^{\mathrm{d}}$ \\
& $\mathrm{LQ}$ & 13.2 & 11.2 & 10.0 & 5.6 \\
& $\mathrm{UQ}$ & 20.2 & 16.5 & 13.8 & 9.9 \\
\hline Wilcoxon test $(\mathrm{P})$ jugular vs. mammary result $^{\#}$ & & $\mathrm{P}=0.001$ & $\mathrm{P}<0.001$ & $\mathrm{P}<0.002$ & $\mathrm{P}<0.001$ \\
\hline Jugular/Mammary ratio $^{*}$ & $\mathrm{M}$ & $1.15^{\mathrm{a}}$ & $1.13^{\mathrm{a}}$ & $1.18^{\mathrm{a}}$ & $1.66^{\mathrm{b}}$ \\
& $\mathrm{LQ}$ & 1.12 & 1.07 & 1.13 & 1.34 \\
& $\mathrm{UQ}$ & 1.20 & 1.19 & 1.23 & 1.91 \\
\hline
\end{tabular}

$\mathrm{M}_{\mathrm{e}}$ - median; LQ - lower quartile; UQ - upper quartile; ${ }^{*}$ Values in a row of median values based on the Mann-Whitney U-test with different superscripts are significantly different $(\mathrm{P}<0.05)$; ${ }^{\text {\#Sig- }}$ nificance levels of the Wilcoxon test between jugular and mammary concentrations

\section{Table 4}

Glucose concentration in jugular and mammary veins and their ratio in dry and milking cows

\begin{tabular}{lccccc}
\hline \multirow{2}{*}{ Glucose concentrations (mmol/L) } & & \multicolumn{4}{c}{ Group } \\
\cline { 3 - 6 } & & DRY & LY & MY & HY \\
\hline Jugular vein $^{*}$ & $\mathrm{M}_{\mathrm{e}}$ & $3.35^{\mathrm{a}}$ & $3.05^{\mathrm{b}}$ & $3.00^{\mathrm{b}}$ & $2.80^{\mathrm{b}}$ \\
& $\mathrm{LQ}$ & 3.15 & 2.65 & 2.50 & 2.45 \\
& $\mathrm{UQ}$ & 3.50 & 3.20 & 3.30 & 2.90 \\
\hline Mammary vein $^{*}$ & $\mathrm{M}_{\mathrm{e}}$ & $3.20^{\mathrm{a}}$ & $2.85^{\mathrm{b}}$ & $2.20^{\mathrm{c}}$ & $1.35^{\mathrm{d}}$ \\
& $\mathrm{LQ}$ & 3.00 & 2.55 & 1.80 & 1.10 \\
& $\mathrm{UQ}$ & 3.30 & 3.05 & 2.30 & 1.90 \\
\hline Wilcoxon test (P) jugular vs. mammary result $^{\#}$ & & $\mathrm{P}=0.001$ & $\mathrm{P}<0.001$ & $\mathrm{P}<0.001$ & $\mathrm{P}<0.001$ \\
\hline Jugular/Mammary ratio $^{*}$ & $\mathrm{M}$ & $1.05^{\mathrm{a}}$ & $1.04^{\mathrm{a}}$ & $1.47^{\mathrm{b}}$ & $2.05^{\mathrm{c}}$ \\
& $\mathrm{LQ}$ & 1.01 & 1.04 & 1.25 & 1.50 \\
& $\mathrm{UQ}$ & 1.06 & 1.07 & 1.68 & 2.41
\end{tabular}

See footnote to Table 3 for explanations

Jugular NEFA concentrations were significantly higher in lactating than in dry cows and also increased significantly with milk production between the groups of lactating cows (Table 5). Mammary NEFA concentrations were also 
higher in lactating than in dry cows. The $\mathrm{J} / \mathrm{M}$ ratios for NEFA concentrations were lower than 1.0 in Groups DRY and LY and above 1.0 in Groups MY and LY. Values of the J/M ratio increased significantly through Groups LY, MY and HY. The Wilcoxon test showed significant differences between jugular and mammary NEFA concentrations in all examined groups of cows, but the probability was borderline for Group MY ( $\mathrm{P}=0.0504$; Table 5).

\section{Table 5}

Non-esterified fatty acid (NEFA) concentration in jugular and mammary veins and their ratio in dry and milking cows

\begin{tabular}{lccccc}
\hline \multirow{2}{*}{ NEFA concentrations (mmol/L) } & & \multicolumn{4}{c}{ Group } \\
\cline { 3 - 6 } & & DRY & LY & MY & HY \\
\hline Jugular vein $^{*}$ & $\mathrm{M}_{\mathrm{e}}$ & $0.16^{\mathrm{a}}$ & $0.30^{\mathrm{b}}$ & $0.50^{\mathrm{c}}$ & $0.80^{\mathrm{d}}$ \\
& $\mathrm{LQ}$ & 0.16 & 0.20 & 0.40 & 0.65 \\
& $\mathrm{UQ}$ & 0.31 & 0.40 & 0.75 & 0.80 \\
\hline Mammary vein $^{*}$ & $\mathrm{M}_{\mathrm{e}}$ & $0.28^{\mathrm{a}}$ & $0.40^{\mathrm{b}}$ & $0.50^{\mathrm{c}}$ & $0.40^{\mathrm{b}}$ \\
& $\mathrm{LQ}$ & 0.25 & 0.40 & 0.40 & 0.25 \\
& $\mathrm{UQ}$ & 0.33 & 0.40 & 0.75 & 0.40 \\
\hline Wilcoxon test (P) jugular vs. mammary result $^{\#}$ & & $\mathrm{P}<0.001$ & $\mathrm{P}<0.001$ & $\mathrm{P}=0.0504$ & $\mathrm{P}<0.001$ \\
\hline Jugular/Mammary ratio $^{*}$ & $\mathrm{M}_{\mathrm{e}}$ & $0.69^{\mathrm{a}}$ & $0.75^{\mathrm{a}}$ & $1.07^{\mathrm{b}}$ & $2.12^{\mathrm{c}}$ \\
& $\mathrm{LQ}$ & 0.57 & 0.50 & 1.00 & 1.77 \\
& $\mathrm{UQ}$ & 0.90 & 1.00 & 1.27 & 2.67 \\
\hline
\end{tabular}

See footnote to Table 3 for explanations

Jugular vein BHBA concentrations increased in the order DRY $<\mathrm{LY}<$ $\mathrm{MY}<\mathrm{HY}$ (Table 6). Mammary vein BHBA levels were significantly lower in Group LY than in dry cows. The other groups of lactating cows (MY and HY) had similar BHBA concentrations in the mammary vein as dry cows. $\mathrm{J} / \mathrm{M}$ ratios for BHBA concentrations were lower than 1.0 in dry cows, but equal to or higher than 1.0 in all lactating cows. The Wilcoxon test detected significant differences between jugular and mammary BHBA concentrations in all examined groups of cows except Group LY (Table 6).

Average jugular vein urea concentrations were not significantly different between the lactating groups of cows but were significantly higher in Groups LY and MY than for the dry group (Table 7). Mammary vein urea concentrations were considerably higher in lactating cows than in the group of dry cows and were 2, 2.63, and 3 times higher in the LY, MY and HY group, respectively, compared to values determined in dry cows . The $\mathrm{J} / \mathrm{M}$ ratios for urea concentrations were higher than 1.0 in dry cows and in Group LY but lower than 1.0 in Groups MY and HY. Differences between the dry cow group and all lactating groups in urea $\mathrm{J} / \mathrm{M}$ ratios 
were significant with much higher ratios in dry and LY cows. As for the lactating groups, in MY and HY cows the urea $\mathrm{J} / \mathrm{M}$ ratio was only $35 \%$ of the $\mathrm{J} / \mathrm{M}$ value found in dry cows. The Wilcoxon test showed significant differences between jugular and mammary urea concentrations in all examined groups of cows except Group LY (Table 7).

\section{Table 6}

Beta-hydroxybutyrate (BHBA) concentration in jugular and mammary veins and their ratio in dry and milking cows

\begin{tabular}{lccccc}
\hline \multirow{2}{*}{ BHBA concentrations (mmol/L) } & \multicolumn{5}{c}{ Group } \\
\cline { 3 - 6 } & & DRY & LY & MY & HY \\
\hline Jugular vein $^{*}$ & $\mathrm{M}_{\mathrm{e}}$ & $0.10^{\mathrm{a}}$ & $0.20^{\mathrm{a}}$ & $0.50^{\mathrm{b}}$ & $0.80^{\mathrm{c}}$ \\
& $\mathrm{LQ}$ & 0.10 & 0.10 & 0.30 & 0.60 \\
& $\mathrm{UQ}$ & 0.30 & 0.35 & 0.70 & 0.90 \\
\hline Mammary vein $^{*}$ & $\mathrm{M}_{\mathrm{e}}$ & $0.30^{\mathrm{a}}$ & $0.20^{\mathrm{b}}$ & $0.25^{\mathrm{ab}}$ & $0.40^{\mathrm{a}}$ \\
& $\mathrm{LQ}$ & 0.30 & 0.10 & 0.10 & 0.10 \\
& $\mathrm{UQ}$ & 0.35 & 0.25 & 0.45 & 0.60 \\
\hline Wilcoxon test (P) jugular vs. mammary result $^{\#}$ & & $\mathrm{P}=0.001$ & $\mathrm{P}=0.328$ & $\mathrm{P}<0.001$ & $\mathrm{P}<0.001$ \\
\hline Jugular/Mammary ratio $^{*}$ & $\mathrm{M}_{\mathrm{e}}$ & $0.33^{\mathrm{a}}$ & $1.00^{\mathrm{b}}$ & $2.00^{\mathrm{c}}$ & $1.90^{\mathrm{c}}$ \\
& $\mathrm{LQ}$ & 0.33 & 0.87 & 1.62 & 1.44 \\
& $\mathrm{UQ}$ & 0.87 & 2.00 & 2.67 & 5.50 \\
\hline
\end{tabular}

See footnote to Table 3 for explanations

\section{Table 7}

Urea concentration in jugular and mammary veins and their ratio in dry and milking cows

\begin{tabular}{lccccc}
\hline \multirow{2}{*}{ Urea concentrations (mmol/L) } & & \multicolumn{4}{c}{ Group } \\
\cline { 3 - 6 } & & DRY & LY & MY & HY \\
\hline Jugular vein $^{*}$ & $\mathrm{M}_{\mathrm{e}}$ & $2.0^{\mathrm{a}}$ & $3.0^{\mathrm{b}}$ & $3.0^{\mathrm{b}}$ & $3.0^{\mathrm{ab}}$ \\
& $\mathrm{LQ}$ & 2.0 & 3.0 & 2.0 & 3.0 \\
& $\mathrm{UQ}$ & 3.0 & 3.5 & 3.0 & 4.0 \\
\hline Mammary vein $^{*}$ & $\mathrm{M}_{\mathrm{e}}$ & $1.5^{\mathrm{a}}$ & $3.0^{\mathrm{b}}$ & $3.95^{\mathrm{c}}$ & $4.5^{\mathrm{c}}$ \\
& $\mathrm{LQ}$ & 1.0 & 2.0 & 3.9 & 4.0 \\
& $\mathrm{UQ}$ & 2.0 & 3.0 & 5.0 & 6.0 \\
\hline Wilcoxon test (P) jugular vs. mammary result $^{\#}$ & & $\mathrm{P}=0.002$ & $\mathrm{P}=0.118$ & $\mathrm{P}=0.002$ & $\mathrm{P}<0.001$ \\
\hline Jugular/Mammary ratio $^{*}$ & $\mathrm{M}_{\mathrm{e}}$ & $1.75^{\mathrm{a}}$ & $1.67^{\mathrm{b}}$ & $0.67^{\mathrm{c}}$ & $0.67^{\mathrm{c}}$ \\
& $\mathrm{LQ}$ & 1.00 & 0.87 & 0.51 & 0.54 \\
& $\mathrm{UQ}$ & 2.00 & 1.50 & 1.00 & 0.83 \\
\hline
\end{tabular}

See footnote to Table 3 for explanations 


\section{Discussion}

The analysis of mammary gland metabolism by comparing concentrations of blood variables obtained simultaneously from the mammary and jugular veins has lost significance since the introduction of assessment using the simultaneous measurement of blood variables from the $a$. intercostalis and $v$. subcutaneous abdominis, i.e. determining the mammary arteriovenous difference (Hanigan et al., 1992; Cant et al., 1993; Rius et al., 2010). Although the composition of jugular blood does not exactly reflect arterial blood composition, close accordance with data based on mammary arteriovenous differences suggests that $\mathrm{J}-\mathrm{M}$ differences can be used to evaluate general trends (Gagliostro et al., 1991). The main reason for using this approach to assess mammary gland activity in lactating cows is the fact that blood sampling from the a. intercostalis needs surgical preparation, which is not easy to perform in routine practice in the field. On the contrary, two veins are much more accessible for blood sampling.

The energy status of cows is usually determined by analysing concentrations of variables obtained only from jugular vein blood (Dyck et al., 2011). In our study, differences in concentrations of the examined variables in jugular vein blood were expected and are in accordance with earlier data (Kida, 2002; Šamanc et al., 2011). Namely, jugular vein insulin concentrations in lactating cows decreased with higher milk production due to the more pronounced NEB during early lactation (Hayirli et al., 2011). Jugular glucose concentrations also differed significantly between the groups of lactating cows but were within the physiological range in all cases $(2.50-4.16 \mathrm{mmol} / \mathrm{L}$, according to Kaneko et al., 2008). Glucose concentration is under tight homeostatic control and therefore is not a good indicator of the cow's energy status (Herdt, 2000). The concentration of jugular NEFA reflects the magnitude of lipid mobilisation from storage and is highly positively correlated with the extent of NEB in early-lactation cows. BHBA indicates the completeness of fatty acid catabolism in the liver. When the supply of NEFA to the liver exceeds its ability to catabolise fatty acids completely, ketone body production increases. Ketone bodies can be used by the muscles as an alternative fuel source to glucose, sparing glucose for milk production. Although jugular vein urea concentrations were significantly higher in Groups LY and MY compared to the group of dry cows, the levels were within the physiological range (3.33-4.99, according to Kaneko et al., 2008). Elevated urea concentrations usually indicate an excess of dietary protein relative to energy supply (Fekete et al., 1996; Tamminga, 2006).

The results obtained for concentrations of variables in the mammary vein indicated that there were differences from the trend of changes in the jugular vein. The jugular to mammary vein ratio $(\mathrm{J} / \mathrm{M})$ shows differences according to milk production more clearly. Namely, if the ratio is higher than 1.0, it indicates that the blood variable is apparently utilised in the mammary gland, while if it is 
lower than 1.0 it indicates apparent mammary release of the metabolite. This interpretation of the results is a slightly modified version of that obtained by Gagliostro et al. (1991), who presented jugular to mammary vein blood differences considering that a positive result indicates that the blood variable is apparently utilised in the mammary gland. In all groups of cows in this study, J/M for insulin and glucose concentrations were higher than 1.0, meaning that those substances were apparently utilised by the mammary gland in all cases. $\mathrm{J} / \mathrm{M}$ ratios for insulin were similar in dry, low- and medium-yielding cows but were significantly higher in high-yielding cows, indicating that the apparent mammary uptake of insulin was greater in those cows. This was expected due to the well-known physiological finding that, although without a direct impact on milk production, insulin is utilised in the lactating mammary gland for milk protein synthesis within bovine mammary epithelial cells (Menzies et al., 2009) and in highyielding cows for mammary cell proliferation (Sorensen et al., 2006). The J/M for glucose was lower in dry and LY cows, while it was significantly higher in Groups MY and HY. This confirms our earlier work where simultaneous glucose concentrations in the $v$. auricularis magna and $v$. subcutanea abdominis were compared (Stamatović et al., 1983). Moreover, glucose is utilised by the mammary gland mainly for lactose synthesis and to supply ATP (through glycolysis and the TCA cycle), as well as for milk fat formation (Guinard-Flament et al., 2006).

The $\mathrm{J} / \mathrm{M}$ ratio for NEFA concentrations in dry and LY cows was lower than 1.0, indicating that in those cows the mammary gland was sufficiently supplied with energy precursors and had no need to use endogenous sources for metabolic activity. J/M for NEFA concentrations in Groups MY and HY was higher than 1.0, suggesting that this metabolite is apparently utilised in mammary glands with higher milk production. The same explanation may be used to interpret the results for BHBA, which indicate an imbalance between mammary gland supply and its needs in cows producing more than 41 litres of milk per day.

The $\mathrm{J} / \mathrm{M}$ ratio for urea concentrations was higher than 1.0 in dry and LY cows but lower than 1.0 in Groups MY and HY. This indicates apparent utilisation of this metabolite by the mammary gland in the dry period, while in cows with higher milk production there is an apparent release of urea. Although there is no exact explanation for this, it may be speculated that in MY and HY cows, when energy requirements of the mammary gland are enhanced, some amino acids may not be entirely used for protein synthesis, leading to increased urea concentrations and apparent release from the mammary gland, probably mainly due to the known action of arginase catalysing the conversion of arginine to ornithine and urea. We presumed the similarity of amino acid composition of jugular vein and arterial blood based on data presented by Hanigan et al. (1991) who reported similarities between coccygeal vein blood and arterial blood in amino acid composition.

In conclusion, measuring concentrations of variables in blood samples taken simultaneously from the jugular and mammary veins of cows should en- 
able a more accurate assessment of the energy status of cows in early lactation than if such variables are determined exclusively in samples obtained from the jugular vein. This refers especially to concentrations of those parameters where the $\mathrm{J} / \mathrm{M}$ ratio changes with increasing milk production from values lower than 1.0 to values higher than 1.0 (NEFA and BHBA) or, conversely, from values higher than 1.0 to values lower than 1.0 (urea). These changes for all three variables occur when milk production is higher than 41 litres. Determination of concentrations of those three metabolites simultaneously in jugular and mammary veins and calculation of their $\mathrm{J} / \mathrm{M}$ ratios may have diagnostic value. Namely, a $\mathrm{J} / \mathrm{M}$ ratio for BHBA and/or NEFA lower than 1.0 and a $\mathrm{J} / \mathrm{M}$ ratio for urea higher than 1.0 indicate that the energy supply to the mammary gland is probably sufficient. On the contrary, when the $\mathrm{J} / \mathrm{M}$ ratio for BHBA and/or NEFA is higher than 1.0 and the $\mathrm{J} / \mathrm{M}$ ratio for urea is lower than 1.0, the energy supply to the mammary gland is insufficient for optimal mammary gland activity. In addition, since the $\mathrm{J} / \mathrm{M}$ ratio for BHBA tended to change from less than 1.0 to more than $1.0 \mathrm{be}$ tween Groups LY and MY, it may be speculated that this variable may be the one that is initially changed when the energy needs for milk production exceed the energy supply.

\section{Acknowledgement}

This work was supported by the Ministry of Science and Technology, Republic of Serbia, Project Grant No 46002.

\section{References}

Cant, J. P., DePeters, E. J. and Baldwin, R. L. (1993): Mammary uptake of energy metabolites in dairy cows fed fats and its relationship to milk protein depression. J. Dairy Sci. 76, 2254-2265.

Cozzi, G., Ravarotto, L., Gottardo, F., Stefani, A. L., Contiero, B., Moro, L., Brscic, M. and Dalvit, P. (2011): Short communication: reference values for blood parameters in Holstein dairy cows: effects of parity, stage of lactation, and season of production. J. Dairy Sci. 94, 3895-3901.

Dyck, B. L., Colazo, M. G., Ambrose, D. J., Dyck, M. K. and Doepel, L. (2011): Starch source and content in postpartum dairy cow diets: effects on plasma metabolites and reproductive processes. J. Dairy Sci. 94, 4636-4646.

Fekete, S., Huszenicza, G., Kellems, R. O., Szakáll, I., Fébel, H., Husvéth, F., Nagy, P., Kulcsár, M., Kósa, E., Gaál, T., Rudas, P. and Oppel, K. (1996): Influence of a deficient intake of high and low degradable protein on body composition, metabolic adaptation, production and reproductive performance in early lactation dairy cows. Acta Vet. Hung. 44, 309-333.

Gagliostro, G., Chilliard, Y. and Davicco, M. J. (1991): Duodenal rapeseed oil infusion in early and midlactation cows: 3 . Plasma hormones and mammary apparent uptake of metabolites. J. Dairy Sci. 74, 1893-1903.

González, F. D., Muiňo, R., Pereira, V., Campos, R. and Benedito, J. L. (2011): Relationship among blood indicators of lipomobilization and hepatic function during early lactation in high-yielding dairy cows. J. Vet. Sci. 12, 251-255. 
Guinard-Flament, J., Delamaire, E., Lemosquet, S., Boutinaud, M. and David, Y. (2006): Changes in mammary uptake and metabolic fate of glucose with once-daily milking and feed restriction in dairy cows. Reprod. Nutr. Dev. 46, 589-598.

Gumen, A., Keskin, A., Yilmazbas-Mecitoglu, G., Karakava, E. and Wiltbank, M. (2011): Dry period management and optimization of postpartum reproductive management in dairy cattle. Reprod. Domest. Anim. 46, 11-17.

Hanigan, M. D., Calvert, C. C., DePeters, E. J., Reis, B. L. and Baldwin, R. L. (1991): Whole blood and plasma amino acid uptakes by lactating bovine mammary glands. J. Dairy Sci. 74, 2484-2490.

Hanigan, M. D., Calvert, C. C., DePeters, E. J., Reis, B. L. and Baldwin, R. L. (1992): Kinetics of amino acid extraction by lactating mammary glands in control and sometribove-treated Holstein cows. J. Dairy Sci. 75, 161-173.

Hayirli, A., Keisler, D. H., Doepel, L. and Petit, H. (2011): Peripartum responses of dairy cows to prepartal feeding level and dietary fatty acid source. J. Dairy Sci. 94, 917-930.

Herdt, T. H. (2000): Variability characteristics and test selection in herd-level nutritional metabolic profile testing. Vet. Clin. North Am. Food Anim. Pract. 16, 387-403.

Kaneko, J. J., Harvey, J. W. and Bruss, M. L. (2008): Clinical Biochemistry of Domestic Animals. Sixth edition. Academic Press, San Diego.

Kida, K. (2002): Use of every ten day criteria for metabolic profile test after calving and dry off in dairy herds. J. Vet. Med. Sci. 64, 1003-1010.

Kirchgessner, M. and Kreuzer, M. (1985): Urea and allantoin in milk of cows during and after provision of too much or too little protein. 5. Effect of an incorrect protein supply for lactating cows and its consequences. J. Anim. Physiol. Anim. Nutr. 54, 141-151.

Laven, R. A., Wathes, D. C., Lawrence, K. E. and Scaramuzzi, R. J. (2007): An analysis of the relationship between plasma urea and ammonia concentration in dairy cattle fed a consistent diet over a 100-day period. J. Dairy Res. 74, 412-416.

Le Blanc, S. (2010): Monitoring metabolic health of dairy cattle in the transition period. J. Reprod. Dev. 56, S29-S35.

Menzies, K. K., Lefèvre, C., Macmillan, K. L. and Nicholas, K. R. (2009): Insulin regulates milk protein synthesis at multiple levels in the bovine mammary gland. Funct. Integr. Genomics 9, 197-217.

Oltner, R. and Wiktorsson, H. (1983): Urea concentrations in milk and blood as influenced by feeding varying amounts of protein and energy to dairy cows. Livest. Prod. Sci. 10, 457-467.

Rius, A. G., Appuhamy, J. A. D. R. N., Cyriac, J., Kirovski, D., Escobar, J., McGilliard, M. L., Bequette, B. J., Akers, R. M. and Hanigan, M. D. (2010): Regulation of protein synthesis in mammary glands of lactating dairy cows by starch and amino acids. J. Dairy Sci. 93, 3114-3127.

Šamanc, H., Kirovski, D., Stojić, V., Stojanović, D., Vujanac, I., Prodanović, R. and BojkovićKovačević, S. (2011): Application of the metabolic profile test in the prediction and diagnosis of fatty liver in Holstein cows. Acta Vet. Beograd 61, 543-553.

Sorensen, M. T., Nøgaard, J. V., Theil, P. K., Vestergaard, M. and Sejrsen, K. (2006): Cell turnover and activity in mammary tissue during lactation and the dry period in dairy cows. J. Dairy Sci. 89, 4632-4639.

Stamatović, S., Šamanc, H. and Jovanović, M. (1983): A comparative examination of glucose concentrations in the blood of v. auricularis magna and v. subcutanea abdominis in dairy cows. Veterinarski glasnik 3, 95-99.

Tamminga, S. (2006): The effect of the supply of rumen degradable protein and metabolisable protein on negative energy balance and fertility in dairy cows. Anim. Reprod. Sci. 96, 227-239. 